FARID MATUK

\title{
MY DAUGHTER LA CHOLA MARTINA
}

posse come back proud to flashing eyes of señoritas they say little lady lords

out west practitioners full of old commercial surf pop echo

or land out west don't work for projection

seas awesome trees

in the wind archive wants the voiceover

the sun ghost Los Angeles a clean

way to hug the young ocean salt air ghosts the cool

expanse of the hour ahead we'd try not to show our eyes until they passed

bright colors these days of baby's coming yeah speech act better than a day

searching eyes can interrupt at least she's in it that's the success

trees shake over brothers or sister trees shadow pools for bird traffic the record doesn't say

Sheriff Barton's posse was a white as cute eye shadow as a model plane they seem to take to the quiet depth of so well dead cuz La Chola mishandled their guns readily shroud the quiet record makes a pond truth and beauty kinsmen 